International Journal of Instruction e-ISSN: 1308-1470 • www.e-iji.net
Received: 26/05/2018

Revision: 12/07/2018

Accepted: 17/07/2018

\title{
Secondary School English Language Teachers' Technological Skills in Bangladesh: A Case Study
}

Md. Abdur Rouf

PhD Student, corresponding author, School of Educational Studies, Universiti Sains Malaysia, Malaysia, rouf777@gmail.com

\section{Abdul Rashid Mohamed}

Prof., School of Educational Studies, Universiti Sains Malaysia, Malaysia, richsesusm@gmail.com

The present article reports a qualitative case study that targeted to investigate the secondary schools (SS) English language (EL) teachers' technological skills in Bangladesh. Educational technology has become an indispensable part of teachinglearning. Technologies for Language Learning and Teaching (TLLT) can provide language learners with exposure to authentic and intelligible language usage. EL teachers, consequently, need to have a good command over TLLT and their effective use. Following a multiple case study approach data were collected from ten EL teachers of five SS through classroom observations, face-to-face interviews, and a structured questionnaire. The findings showed that most teachers had basic technology skills but they made ineffective pedagogic use of technology. They need to use technology more often in classroom and develop pedagogical understanding of technology use for teaching English.

Keywords: EL teachers, secondary schools (SS), technology, skills, case study, EFL

\section{INTRODUCTION}

Technology, in the last two or three decades, has affected almost all areas of human works (Praag \& Sanchez, 2015). Everywhere - aviation, entertainment industry, medical science, factory production, global communication, and printing - technology has become essential. Different technological tools like Google, Facebook, cloud computing, mobile devices, YouTube have changed people's ways of living, working and communicating with one another. New technologies along with economic and social pressure of globalisation have created a new world (Mishra et al., 2012). Serviceoriented capitalist global labour market has created demands for a workforce skilled in modern technology (Tour, 2012). As teachers are mainly responsible for producing skilled human resources, the emergence of modern digital technologies (DT), consequently, has implications for all sectors including education.

Citation: Rouf, M. A., \& Mohamed, A. R. (2018). Secondary School English Language Teachers' Technological Skills in Bangladesh: A Case Study. International Journal of Instruction, 11(4), $701-$ 716. https://doi.org/10.12973/iji.2018.11444a 
For different purposes, technology is being used for a long time in education domain. Though DTs have been developed mainly for business and work (Mishra \& Koehler, 2006), teachers are using computer technology since the early 1980s (Mirzajani, Mahmud, Ayub, \& Wong, 2016) for its different affordances. First, technology facilitates to prepare lesson plans, class outlines, develops quiz and examination. Second, technology enhances learners' motivation and engagement in activities improving retention rates. Third, DTs promote autonomous learning, and help schools to establish wider connections with the outside world through curriculum and classroom practices (Hammond, 2014; Uluyol \& Sahin, 2016).

Like in general education, technology can prepare EL learners better for job markets as employment pattern is changing fast in the second decade of $21^{\text {st }}$ century due to the developments in technology, and globalisation. In Bangladesh most EL learners get no chance to communicate directly with native speakers. They are rarely exposed to the cultural features of the target language (TL). TLLT create a unique opportunity for learners to know linguistic and cultural aspects of the TL. Additionally, DTs help EL learners develop survival skills- communication, collaboration, information gathering etc. In the present global labour market these skills are highly essential (Healey et al., 2011). Learners must develop both linguistic skills and digital literacy; thus, technologically skilled EL teachers can enhance learners' employability. Technologies for Language Learning and Teaching (TLLT) are used all over the world for classroom instructions by L2 teachers (Tour, 2015; Blake, 2016; Godwin-Jones, 2015; Getenet, Beswick, \& Callingham, 2014).

Teachers play a significant role for technology integration in classrooms. They should know how to use technology effectively in classroom instruction (Richards, 2010). Teachers with high motivation use technology in classrooms more often than teachers with low motivation (Uluyol \& Sahin, 2016; Ertmer, 2005). If teachers understand how technologies can be used in diverse ways to present contents, it would enrich their pedagogical practices (Mishra et al., 2012; Godwin-Jones, 2015). Besides, teachers' classroom practices are influenced by their attitudes and beliefs. Pajares (1992 cited in Ertmer, 2005) mentioned that teachers' pedagogical practices are more influenced by their beliefs than their knowledge. They must believe in the effectiveness of DTs, otherwise they won't be interested in using technology in classrooms.

Integration of ICT at all levels of education is one main objective of the present government in Bangladesh. National ICT policy-2009 recommended incorporating technology in primary and secondary schools. The policy envisioned to raise education quality by integrating ICT in education with a focus on English, Science and Mathematics. The Ministry of Education (MOE) also directed all the SS to arrange listening and speaking practices for learners using DTs. Besides, different teacher training projects are also encouraging EL teachers to use technology for their professional development (PD) in Bangladesh (Karim, Mohamed, \& Rahman, 2017). 


\section{Conceptual Framework}

This study addressed the issue of EL teachers' technological skills through a conceptual framework that was mainly informed by TESOL Technology Standards for English Language Teachers developed by Healey et al. (2011) as shown in Figure 1.

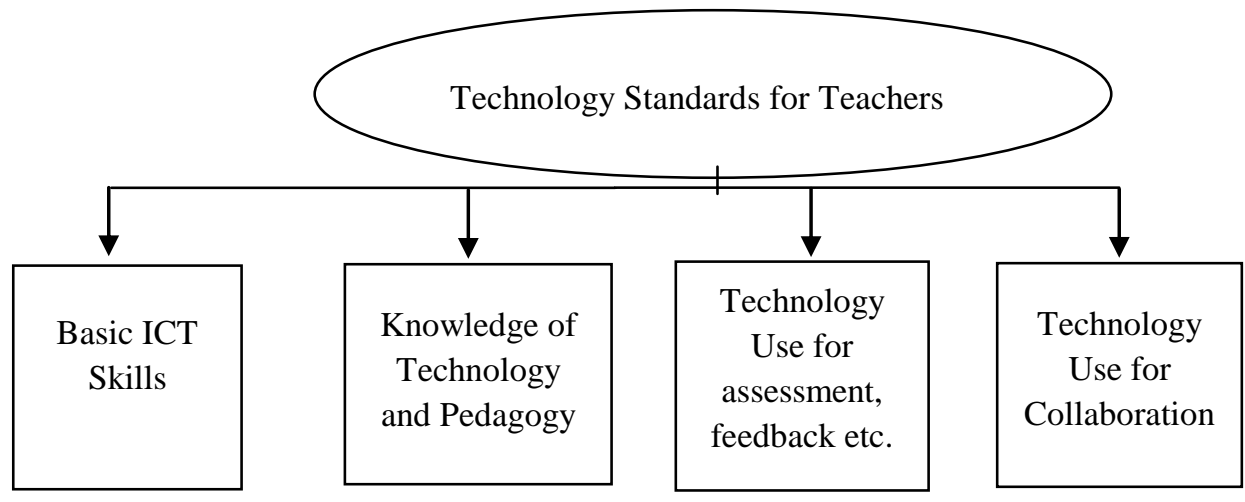

Figure 1

TESOL technology standards for English language teachers

According to the standards, the EL teachers first need fundamental knowledge and skills in ICT- digital devices, software, and appropriate technology selection. Second, they have to combine their pedagogical and technological knowledge for effective instruction, e.g. they must know about schools' technology facilities, their limitations, level of learners' technology competency, and always rethink their teaching approach for effectiveness. Third, use of technology for assessment, feedback and record-keeping is essential. Finally, teachers must use technology for collaboration, networking, and skill enhancement through sharing materials, email with colleagues, students, and becoming members of online language teachers' communities.

This paper is organized in six parts. The paper starts with an introduction to the topic, describes its background, and presents the conceptual framework; the second part presents a succinct review of the relevant literature; the third part focuses on the methodology used; the findings are then presented; the fifth part discusses the results and mentions some implications for the EL teachers and other stakeholders. Finally, it presents limitations of the study and suggestions for further research.

\section{REVIEW OF LITERATURE}

Tour (2015) investigated language teachers' $(n=3)$ use of technology in personal and professional life in Australia. The findings indicated an alignment between technology use in teachers' personal and professional life. The teachers used technology for both orthodox and innovative classroom practices. However, DelliCarpini (2012) found that teachers' $(n=53)$ technology use in personal life did not influence their use of technology in classrooms in the USA. 
In another study Yuksel and Yasin (2014) found that primary and SS EL teachers $(\mathrm{n}=124)$ in Turkey had moderate competency in technology, pedagogy, and content knowledge (TPACK). The young teachers had better technological knowledge (TK) and they used technology more often than the experienced teachers. Teachers' gender did not exert considerable influence on TPACK. Again, Bilici, Guzey, and Yamak (2016) in their study found that pre-service science teachers $(n=27)$ in Turkey demonstrated technology, pedagogy, and content knowledge (TPACK) in microteaching and lesson plans. They could use technology but their technology use was teacher-centred.

Mirzajani et al. (2016) in Iran found that several factors- training on technology, availability of resources, administrative and technical support, time, willingness of teachers to use ICT, teachers' skills and self-confidence influenced teachers' $(n=4)$ enthusiasm for using technology. When Ottenbreit-Leftwich, Glazewski, Newby, and Ertmer (2010) investigated teachers' $(n=8)$ beliefs that motivated them to use technology in the USA, teachers mentioned two reasons for using technology: (1) to meet their own professional needs and (2) students' need. Record keeping, correspondence with parents, newsletters development, classroom materials preparation and professional development (PD) were done by teachers using technology.

Getenet et al. (2014) through an intervention in the form of a workshop on TPACK investigated the impact of training on Ethiopian primary school teachers' ICT use. In the pre-intervention stage teachers informed that resource scarcity, poor knowledge of ICT, lack of awareness and limited training affected their technology use. After attending the workshop with other colleagues, they became skilled in ICT and developed TPACK. Well-designed PD trainings help teachers to be skilled in technology use in classrooms.

Shohel and Power (2010) assessed the English in Action (EIA) project that aimed to help teachers' engagement in PD independently by providing them mobile technology with pre-loaded audio-visual materials in Bangladesh. The results showed that teachers' pedagogic skills and classroom language proficiency improved. Anwaruddin (2016), however, questioned EIA's approach to teachers' PD using technology. Using the lens of 'New Materialist' discourse, he argued that EIA emphasized teachers' skill enhancement but contexts of teachers' work, their learning experiences as students, and pedagogical practices were ignored. Moreover, EIA's top-down approach to technology use did not help to develop teacher agency, and teachers could not experiment with preloaded language teaching materials. He recommended having a critical look at technology, and connecting DTs and contexts keeping in mind the neoliberal 'corporate' interest in educational technology.

Reviewed studies above focused on different aspects of teachers' technology use, and their skills; they were conducted in different contexts, e.g. Australia, the USA, Turkey, the UK, Iran, Ethiopia, and Bangladesh. Overall, very few studies have been done on non-government SS EL teachers' technological skills in Bangladesh. 


\section{METHOD}

The main objective of this study was to explore the SS EL teachers' technological skills particularly their classroom operational skills in technology. The study, accordingly, was carried out based on the following research question (RQ):

RQ: What type of technological skills do the SS EL teachers possess?

Following the qualitative paradigm, a multiple case study approach was used to carry out this study (Stake, 2006; O'Brien, Harris, Beckman, Reed, \& Cook, 2014). Researchers have used the case study approach as it helps gain in-depth insights on the studied entity (Yazan, 2015; Creswell, 2007). Miles and Huberman (1994) explained a case as "a phenomenon of some sort occurring in a bounded context. The case is, in effect, your unit of analysis. Studies may be of just one case or of several" (p.25). The qualitative design of this study helped obtain 'deep data' on the EL teachers' technology skills.

\section{Rigour of the study}

The main concern for qualitative researchers is the maintenance of rigour i.e. trustworthiness of their studies (Baškarada, 2014). According to Robson (2011), trustworthiness indicates the trust of readers in the methodology and findings of a qualitative study. Unlike quantitative study, reliability and validity of qualitative study is ensured by maintaining the trustworthiness mainly through methodological approaches (Noble \& Smith, 2015). Lincoln and Guba (1985) asserted that the principal criteria for assessing trustworthiness of a qualitative investigation are credibility, dependability, confirmability and transferability. Necessary steps were taken to ensure the rigour of this study that included maintaining a case study data base, collecting data from various sources using different methods, staying at the schools with the participating teachers for long time, and using self-reflections to avoid bias (Baškarada, 2014; Berger, 2013).

\section{Participants}

For conducting this study on the non-government SS EL teachers, ten teachers (T1-T10) were selected from five SS in Dhaka, Bangladesh using a purposive sampling technique. Purposive sampling technique was used for participant selection to gather rich data on the examined issues (Stake, 1995). The number of sample cases was ten to facilitate analysis across cases and ensure the reliability of findings. At the beginning, the teachers were briefed on the study's objective, and formally requested to participate. They were informed that their privacy would be preserved with utmost care, and they could opt for withdrawal at any point of the study (Chenail, 2011; Praag \& Sanchez, 2015; Hamid, 2010). Teachers have been given alpha-numeric label (T1-T10) throughout this paper to preserve their anonymity (Zein, 2016; Ambler, 2016). Table 1 presents demographic details of the participating EL teachers. 
Table 1

Demographic data on the participating SS EL teachers (T1-T10)

\begin{tabular}{llcc}
\hline Participants & Gender & Age (Years) & Teaching Experience (Years) \\
\hline T1 & Female & 47 & 21 \\
\hline T2 & Female & 30 & 7 \\
\hline T3 & Male & 42 & 21 \\
\hline T4 & Male & 50 & 22 \\
\hline T5 & Female & 58 & 34 \\
\hline T6 & Male & 50 & 20 \\
\hline T7 & Male & 58 & 31 \\
\hline T8 & Male & 38 & 12 \\
\hline T9 & Male & 40 & 16 \\
\hline T10 & Female & 39 & 10 \\
\hline
\end{tabular}

\section{Data Collection Tools}

For data collection on teachers' technology skills, three instruments were developed: (1) a semi-structured classroom observation guide; (2) a semi-structured interview checklist; and (3) a structured questionnaire on teachers' self-reported technology skills. The validity and reliability of the developed instruments were ensured in three ways: (1) related literature review; (2) expert opinion; and (3) a pilot study. First, all the tentative items of the three instruments were matched against relevant literature (Healey et al., 2011; Mishra \& Koehler, 2006; Getenet et al., 2014; Tour, 2015; Mishra et al., 2012; Koehler \& Mishra, 2009; Hammond, 2014; Ertmer, 2005; Blake, 2016) on teachers' technology skills. Second, two experts - one from Bangladesh and another from Malaysia - gave their opinions on the instruments, and their suggestions were duly included in the final versions. Finally, a pilot case study was carried out in a SS in Dhaka, Bangladesh with EL teachers to assess the suitability of the developed instruments (Elo et al., 2014; Yin, 2009). The pilot study showed that the instruments could elicit reliable and adequate data on teachers' technology skills.

\section{Procedures for Data Collection}

Fieldwork for data collection was carried out during February 2017 to July 2017. Data on teachers' technological skills was collected following three procedures: (1) observing classrooms using a semi-structured observation guide; (2) interviewing individual teachers using a semi-structured checklist (Merriam, 1988); and (3) using a structured questionnaire. The questionnaire helped to save time by eliciting respondents' answers to twenty closed-ended items. Consulting the participating teachers, a detailed schedule was developed for classroom observations and face-to face interviews. The first author carried out fifty-five non-participant direct classroom observations to get data on teachers' technology use in classrooms (Tellis, 1997). Concurrently, the questionnaire was administered with the teachers. Once class observations were over, individual faceto-face interviews were conducted with the teachers. Interview data were recorded using a professional voice recorder, and all collected data were preserved securely. 


\section{Data Analysis}

When the data collection phase was over, the interview data were verbatim transcription. An iterative approach was followed for data analysis throughout the study. For data analysis, thematic analysis (TA) was used as advocated by Braun \& Clarke (2006). TA analysis was done in six phases as shown in Figure 2. Interviews with the participating teachers were conducted in L1 (Bengali), and the first author has translated the quoted excerpts in English.

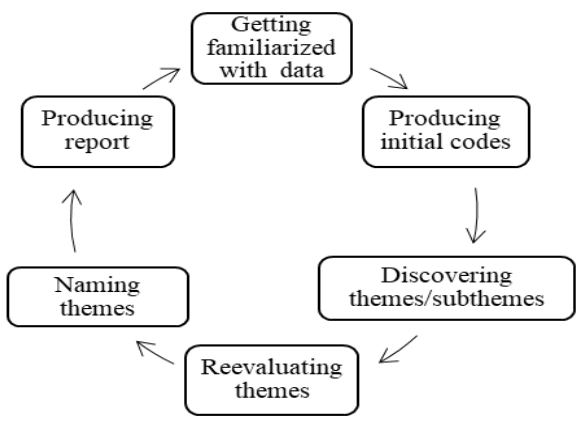

Figure 2

Six Phases of Thematic Analysis

For ensuring the reliability of findings, collected data were analysed in its entirety to avoid partial presentation of results. Moreover, through member checking findings were confirmed (Berger, 2013). Detailed descriptions of the findings supported by raw data are given below.

\section{FINDINGS}

\section{Limited Technology Facilities in Schools and EL Classrooms}

The participating five schools had inadequate technological facilities. Though each of the schools had one ICT lab with some computers, multimedia projectors, only three schools could manage sound system for those labs. However, in S4 (school-4) and S5 the ICT labs were dysfunctional, and teachers did not use them for teaching classes. In S4 teachers conducted multimedia classes (MC) by setting DTs in a specific classroom on temporary basis. Only S3 had permanent and fixed DTs in seven of its regular classrooms; no other schools had DTs in regular classrooms.

Moreover, in S5 the participating teachers did not use DTs at all for language teaching and they received no training on technology use. As the schools had inadequate technological facilities, teachers could not arrange regular MC. According to teachers, respective school authority showed positive attitude to technology use and encouraged teachers to use DT in classes. T1, T2, T3, T4, T5, T6, T7 had the arrangement to use professional computers in schools but $\mathrm{T} 6$ and $\mathrm{T} 7$ practically did not use technology; T8, 
T9, T10 could not use professional computers in schools. They used their personal laptops for professional purposes.

\section{Learners' Profound Interest in Technology}

According to teachers, learners used DTs in their personal life, and they had deep interest in modern technology. Technology use in language classrooms helped to retain their interest.

Learners are very interested in technology; they have advanced technology skills, and are very attentive in MC. (T3)

At present learners are interested in anything that is screen-based. (T8)

Considering learners' personal use of and interest in technology, EL teachers need to incorporate technology in classrooms.

\section{Technology Use in Teachers' Personal Life}

As shown in Table 2 below, participating teachers used DTs particularly cell phones and computers in their personal life for various reasons: for communicating with others, sending texts, exchanging pictures, chatting, gathering information, living modern life, searching documents, using the Internet, maintaining social relations, remaining updated and connected; for entertainment: listening to music, watching movies etc. Most of the teachers $(\mathrm{n}=8)$ had internet access at home and all of them were interested in new DTs.

Table 2

Teachers' attitude towards and personal use of technology

\begin{tabular}{llc}
\hline Item & Yes & No \\
\hline $\begin{array}{l}\text { Using mobiles, computers and } \\
\text { other technologies in personal life }\end{array}$ & T1, T2, T3, T4, T5, T6, T7, T8, T9, T10 & \\
\hline Access to Internet at home & T1, T2, T3, T4, T5, T8, T9, T10 & T6, T7, \\
\hline $\begin{array}{l}\text { Interest in new technology } \\
\begin{array}{l}\text { Technologies play an effective role } \\
\text { in teaching-learning English }\end{array}\end{array}$ & T1, T2, T3, T4, T5, T6, T7, T8, T9, T10 & \\
\hline
\end{tabular}

\section{Teachers' Belief in the Effectiveness of Technology}

All the participating teachers strongly believed that DTs can play an effective role in teaching-learning English.

Time is changing so we must use ICT in language teaching-learning. (T7)

Technology is a revolutionary change maker; makes student interested in class. (T9)

They all showed a positive attitude towards using technology for language classes as it helps to make digital contents, teach classes with multimedia for audio/visual presentation, practise pronunciation, observe body language of speakers, create 
innovative and interesting materials, teach vocabulary with visuals, develop listening and speaking skills by listening to and watching native speakers.

\section{Teachers' Technology Skills}

Table 3

Data on teachers' technological skills

\begin{tabular}{|c|c|c|}
\hline Item & Yes & No \\
\hline Having training on technology use & $\mathrm{T} 1, \mathrm{~T} 2, \mathrm{~T} 3, \mathrm{~T} 10$ & $\begin{array}{l}\text { T4, T5, T6 } \\
\text { T7, T8, T9 }\end{array}$ \\
\hline $\begin{array}{l}\text { Schools having technological } \\
\text { facilities for arranging listening and } \\
\text { speaking practice }\end{array}$ & T3, T8, T9, T10 & $\begin{array}{l}\text { T1, T2, T4, } \\
\text { T5, T6, T7 }\end{array}$ \\
\hline $\begin{array}{l}\text { Using technology for maintaining } \\
\text { class records, attendance, and grading }\end{array}$ & & $\begin{array}{l}\text { T1, T2, T3, T4 } \\
\text { T5, T6, T7, T8, } \\
\text { T9, T10 }\end{array}$ \\
\hline $\begin{array}{l}\text { Skills to make PowerPoint } \\
\text { presentations }\end{array}$ & $\mathrm{T} 1, \mathrm{~T} 2, \mathrm{~T} 3, \mathrm{~T} 5, \mathrm{~T} 8, \mathrm{~T} 10$ & T4, T6, T7, T9 \\
\hline $\begin{array}{l}\text { Using PowerPoint presentations in } \\
\text { classes }\end{array}$ & $\begin{array}{l}\text { T1, T2, T3, T5, T8, T9, } \\
\text { T10 }\end{array}$ & $\mathrm{T} 4, \mathrm{~T} 6, \mathrm{~T} 7$ \\
\hline $\begin{array}{l}\text { Using email for professional } \\
\text { purposes }\end{array}$ & $\mathrm{T} 1, \mathrm{~T} 3, \mathrm{~T} 5, \mathrm{~T} 6, \mathrm{~T} 8, \mathrm{~T} 10$ & $\mathrm{~T} 2, \mathrm{~T} 4, \mathrm{~T} 7, \mathrm{~T} 9$ \\
\hline Skills to type Word document & $\begin{array}{l}\text { T1, T2, T3, T7, T8, T9, } \\
\text { T10 }\end{array}$ & T4, T5, T6 \\
\hline Skills to turn a computer on and off & $\begin{array}{l}\text { T1, T2, T3, T4, T5, T6, T8, } \\
\text { T9, T10 }\end{array}$ & $\mathrm{T} 7$ \\
\hline $\begin{array}{l}\text { Skills to open, close and resize } \\
\text { software windows }\end{array}$ & $\begin{array}{l}\text { T1, T2, T3, T4, T5, T8, } \\
\text { T10 }\end{array}$ & T6, T7, T9, \\
\hline $\begin{array}{l}\text { Skills to copy, cut, and paste } \\
\text { elements within a document }\end{array}$ & $\mathrm{T} 1, \mathrm{~T} 2, \mathrm{~T} 3, \mathrm{~T} 8, \mathrm{~T} 9, \mathrm{~T} 10$ & $\mathrm{~T} 4, \mathrm{~T} 5, \mathrm{~T} 6, \mathrm{~T} 7$ \\
\hline $\begin{array}{l}\text { Skills to save, edit, and organize } \\
\text { files and folders }\end{array}$ & $\begin{array}{l}\text { T1, T2, T3, T5, T8, T9, } \\
\text { T10 }\end{array}$ & T4, T6, T7 \\
\hline $\begin{array}{l}\text { Being familiar with word-processing } \\
\text { software and presentation software }\end{array}$ & $\mathrm{T} 1, \mathrm{~T} 2, \mathrm{~T} 8, \mathrm{~T} 10$ & $\begin{array}{l}\text { T3, T4, T5, } \\
\text { T6, T7, T9 }\end{array}$ \\
\hline $\begin{array}{l}\text { Having access to an educational } \\
\text { community supportive of technology } \\
\text { integration }\end{array}$ & $\mathrm{T} 1, \mathrm{~T} 2, \mathrm{~T} 8, \mathrm{~T} 10$ & $\begin{array}{l}\text { T3, T4, T5, } \\
\text { T6, T7, T9 }\end{array}$ \\
\hline
\end{tabular}

Only four teachers got training on ICT as mentioned in Table 3 above; two of them were trained by government agency and two had in-house training on ICT. Other teachers received no training at all. These untrained teachers acquired their existent technological skills by personal technology use and reading books on technology.

Among the ten teachers, four teachers reported that their schools have technological facilities for arranging listening and speaking practice but none of the teachers was found to arrange listening and speaking practices using DTs. Only one teacher (T9) claimed that he sometimes used cell phone for practising those skills in classes. Though 
all teachers used personal cell phone, only $\mathrm{T} 2$ and $\mathrm{T} 9$ sometimes used them for pedagogical purposes.

Teachers can use cell phone for practising listening and speaking skills. (T5)

To date the EL teachers were not using DTs for maintaining class records, attendance, and grading; they carried out these activities manually. It kills much of class time and creates additional workload. Though most teachers could make and use PowerPoint presentations, they were not interested in making their own digital contents (DC) rather they downloaded readymade DC from different sources and used them in MC. Six teachers claimed that they download materials from the website (known as Teacher Batawan) of the Ministry of Education.

As for email use for professional purposes, six teachers stated that they used email, other four did not. The limited use of email by teachers can be partially explained by the fact that teachers hardly collaborated on academic issues with colleagues and students. Most teachers (see Table 3) had basic skills to use technology tools though the rest had noticeable lacking. Only four teachers were familiar with word-processing software and presentation software; this indicated teachers' surface-level skills in DTs. The fact that only four teachers had access to an educational community supportive of technology integration highlighted, again, the absence of collaboration among teachers.

Table 4

Frequency of teachers' technology use for different purposes

\begin{tabular}{|c|c|c|c|c|}
\hline Item & Always & Very often & Sometimes Rarely & Never \\
\hline $\begin{array}{l}\text { Using } \\
\text { technology } \\
\text { for class } \\
\text { preparation }\end{array}$ & & $\mathrm{T} 2, \mathrm{~T} 5, \mathrm{~T} 8$ & $\begin{array}{l}\text { T1, T3, T6, } \\
\text { T9, T10 }\end{array}$ & $\mathrm{T} 4, \mathrm{~T} 7$ \\
\hline $\begin{array}{l}\text { Using } \\
\text { technology } \\
\text { for } \\
\text { developing } \\
\text { class } \\
\text { materials }\end{array}$ & & $\mathrm{T} 2, \mathrm{~T} 8$, & $\begin{array}{l}\text { T1, T3, T4, } \\
\text { T5, T9, } \\
\text { T10 }\end{array}$ & T6, T7, \\
\hline $\begin{array}{l}\text { Using online } \\
\text { materials for } \\
\text { professional } \\
\text { development }\end{array}$ & & $\mathrm{T} 2$ & $\begin{array}{l}\text { T1, T3, T5, } \\
\text { T6, T8, T9, } \\
\text { T10 }\end{array}$ & $\mathrm{T} 4, \mathrm{~T} 7$ \\
\hline
\end{tabular}

The emerging scenario of teachers' DT use for class preparation was not encouraging. Only three teachers very often used technology for class preparation. Surprisingly, two teachers never used technology for class preparation. Moreover, only two teachers used technology very often for developing class materials; two teachers never developed materials using technology. By using DTs teachers made contents, downloaded picture, searched for word meaning, edited materials, looked for grammar structure, graph, teaching aids, and watched recorded model classes. Only one teacher very often used online materials for PD. 


\section{EL Teachers' Digital Technology Use in Classrooms}

The EL teachers did not arrange regular MC and, as already mentioned, teachers most often used downloaded readymade DC in classrooms; they even did not edit the downloaded materials for adaptation. Teachers then rarely used audio/video materials that would expose learners to standard/native English. Only T8 had skills to set up digital teaching materials in classrooms, other teachers needed support to set up their digital equipment. They rarely went online and used online materials while teaching classes. Teachers, except for T9, were not confident in classroom technology use.

\section{Ineffective Pedagogic Use of Digital Technologies (DT)}

In general, the teachers failed to use DT effectively in language classes. Their technology use was predominantly teacher-centred. In MC learners had very limited involvement; they mainly looked at the screen and listened to teachers' lecture. Most teachers skipped language tasks in MC, and there was no pair and group work, even individual work that would help learners to practise the TL. Only two teachers did some pair and group work, and involved learners in language production. Thus, like regular classes MC also became one-man-show run by teachers. MCs were used by teachers usually for image and information presentation on content and language, not for language use or production. Students then were never allowed to use technology in classes. While teaching, teachers went fast to show all the slides they had and made no creative and critical use of DTs rather used them as additional teaching aids. The participating teachers opined that DTs must be used more effectively in language classes.

Students are not learning the language thorough ICT. (T5)

At present ICT is not being very effectively used for language teachinglearning. (T10)

\section{DISCUSSION}

The schools had inadequate technology facilities, and the teachers' technology use was largely ICT lab based. Some schools' financial constraint could explain their poor technology infrastructure. Besides, both the teachers and school authority concerned lacked motivation to arrange more technology facilities. The teachers believed in the effectiveness of technology, and used DTs in personal life, but their classroom technology use was not aligned with their belief and personal use (DelliCarpini, 2012). Though all the schools had technology facilities to a varying extent, some teachers did not use technology at all for language teaching-learning (Yuksel \& Yasin, 2014) which could be explained by their lack of seriousness and skills. Moreover, they did not receive enough training on technology and some teachers were totally untrained. Previous studies found that training on technology affects teachers' interest for technology use (Mirzajani et al., 2016; Şen \& Temel, 2016), and training helps teachers to develop their technology skills (Getenet et al., 2014). Teachers need continuous training to keep updated as technology changes very fast (Mishra et al., 2012).

Most of the teachers had basic technology skills but some even did not have the basic as 
recommended by Healey et al. (2011). Moreover, their technology use was confined to PowerPoint presentations only. No teacher used technology for assessment, feedback and record-keeping. Unlike the teachers in the study of Ottenbreit-Leftwich et al. (2010), only a few teachers very often used technology for class preparation, material development, and PD. They could easily expose the learners to native, standard English by using different audio, video materials but they rarely did that. Moreover, the culture of using technology for collaboration, networking and skills enhancement was missing. They rarely shared materials, and collaborate on academic and PD issues.

The teachers failed to use technology effectively for teaching English as argued in previous studies (Richards, 2010; Healey et al., 2011), and lacked skills to use DT for diverse presentation of materials as advocated by Godwin-Jones (2015). The learners were really interested in technology but in teacher-dominated MC (Bilici et al., 2016) they were scarcely involved in language tasks; consequently, learners were deprived of opportunities to practise the four skills of EL using technology. Additionally, learners were not developing skills for communication, collaboration, information gathering etc. as recommended by Healey et al. (2011). The teachers were unable to combine technology with their pedagogic knowledge, and they did not review their teaching approach from time to time. Short class duration was also a contributing factor to ineffective use of technology. Thus, despite some policy level initiatives by the government of Bangladesh to widen technology use in education, the reality was not encouraging (EIA, 2009b cited in Shohel \& Power, 2010). Obviously, both extrinsic lack of technology facilities, time, training, financial constraint and intrinsic barriers school culture, teachers' skills (Uluyol \& Sahin, 2016; Yuksel \& Yasin, 2014) negatively affected DT use in classroom. All the stakeholders need to remember that technology itself cannot improve EL teaching-learning, teachers have to use technology innovatively considering their contexts (Mishra \& Koehler, 2006; Anwaruddin, 2016).

\section{Recommendations for EL Teachers and Other Stakeholders}

a) Secondary schools must gradually manage more technological facilities in all regular classrooms, not only in ICT labs; some schools' financial constraint has to be addressed.

b) All the teachers must be adequately trained on technology use to enhance skills and confidence.

c) Effective monitoring is needed to ensure teachers' regular use of technology in language classes; head teachers can play an important role in this regard.

d) The EL teachers must develop the skills to arrange listening and speaking practices for learners using technology.

e) Individual teachers should be skilled to prepare his/her own digital contents, and use appropriate aural and visual materials for exposing learners to standard English.

f) For collaboration and professional development teachers need to use technology more.

g) Class duration must be extended to at least 60 minutes for effective technology use. 
h) Ensuring that teachers are using technology in pedagogically sound ways is essential. More focus is needed on teachers' creative and critical use of technology in language class.

\section{CONCLUSION AND SUGGESTIONS FOR FURTHER RESEARCH}

The $21^{\text {st }}$ century learners at present have different platforms for learning away from formal classrooms. DTs have created many tools like YouTube, Google and other outlets for learning. For this unprecedented development, it would be challenging for teachers to retain learners' interest in classes without using DT. However, the participating teachers' poor technology skills implied that they were not ready to exploit technology for effective language teaching, and they need to enhance their digital literacy.

The present study has some limitations. As true for all case studies, it was not intended to generalize the findings of the present study. It was then conducted only in SS in Dhaka; future researches can be carried out with samples from all over Bangladesh. Researchers might explore technological skills of teachers of all other subjects.

\section{Acknowledgement}

The study reported here was funded through a GA scheme by Institute of Postgraduate Studies (IPS), Univesiti Sains Malaysia. The authors would like to thank the two anonymous reviewers for their comments on an initial draft of this paper.

\section{REFERENCES}

Ambler, T. B. (2016). The day-to-day work of primary school teachers: A source of professional learning. Professional Development in Education, 42(2), 276-289. doi: http://dx.doi.org/10.1080/19415257.2014.998343

Anwaruddin, S. M. (2016). ICT and language teacher development in the global south: A new materialist discourse analysis. Educational Studies, 52(3), 260-278. doi: $10.1080 / 00131946.2016 .1169183$

Baškarada, S. (2014). Qualitative case study guidelines. The Qualitative Report, 19(40), $1-25$.

Berger, R. (2013). Now I see it, now I don't: Researcher's position and reflexivity in qualitative research. Qualitative Research, 15(2), 219-234. doi: $10.1177 / 1468794112468475$

Bilici, S. C., Guzey, S. S., \& Yamak , H. (2016). Assessing pre-service science teachers' technological pedagogical content knowledge (TPACK) through observations and lesson plans. Research in Science \& Technological Education, 34(2), 237-251. doi: $10.1080 / 02635143.2016 .1144050$

Blake, R. (2016). Technology and the four skills. Language Learning \& Technology, 20(2), 129-142. 
Chenail, R. J. (2011). Interviewing the investigator: Strategies for addressing instrumentation and researcher bias concerns in qualitative research. The Qualitative Report, 16(1), 255-262.

Creswell, J. W. (2007). Qualitative inquiry and research design: Choosing among five approaches (2nd ed.). Thousand Oaks, CA: Sage.

DelliCarpini, M. (2012). Building computer technology skills in TESOL teaccher education. Language Learning \& Technology, 16(2), 14-23.

Elo, S., Kaariainen, M., Kanste, O., Polkki, T., Utriainen, K., \& Kyngas, H. (2014). Qualitative content analysis: A focus on trustworthiness. SAGE Open, 4(1), 1-10. doi: $10.1177 / 2158244014522633$

Ertmer, P. A. (2005). Teacher pedagogical beliefs: The final frontier in our quest for technology integration? ETR\&D, 53(4), 25-39.

Getenet, S. T., Beswick, K., \& Callingham, R. (2014). Professionalizing in- service teachers' focus on technological pedagogical and content knowledge. Education and Information Technologies, 21(1), 19-34. doi: 10.1007/s10639-013-9306-4

Godwin-Jones, R. (2015). The evolving roles of language teachers: Trained coders, local researchers, global citizens. Language Learning \& Technology, 19(1), 10-22.

Hamid, M. O. (2010). Fieldwork for language education research in rural Bangladesh: Ethical issues and dilemmas. International Journal of Research \& Method in Education, 33(3), 259-271. doi: 10.1080/1743727x.2010.511714

Hammond, M. (2014). Introducing ICT in schools in England: Rationale and consequences. British Journal of Educational Technology, 45 (2), 191-201. doi: doi:10.1111/bjet.12033

Healey, D., Hanson-Smith, E., Hubbard, P., Ioannou-Georgiou, S., Kessler, G., \& Ware, P. (2011). TESOL technology standards: Description, implementation, integration. Alexandria, VA: TESOL International.

Karim, A., Mohamed, A. R., \& Rahman, M. M. (2017). EIA- a teacher education project in Bangladesh: An analysis from diversified perspectives. International Journal of Instruction, 10(4), 51-66. doi: https://doi.org/10.12973/iji.2017.1044a

Koehler, M. J., \& Mishra, P. (2009). What is technological pedagogical content knowledge? Contemporary Issues in Technology and Teacher Education, 9(1), 60-70.

Lincoln, S. Y., \& Guba, E. G. (1985). Naturalistic inquiry. Thousand Oaks, CA: Sage.

Merriam, S. B. (1988). Case study research in education: A qualitative approach. San Francisco, CA: Jossey-Bass Publishers.

Miles, M. B., \& Huberman, A. M. (1994). Qualitative data analysis: An expanded sourcebook (2nd ed.). Thousand Oaks, CA: Sage. 
Mirzajani, H., Mahmud, R., Ayub, A. F. M., \& Wong, S. L. (2016). Teachers' acceptance of ICT and its integration in the classroom. Quality Assurance in Education, 24 (1), 26 - 40. doi: http://dx.doi.org/10.1108/QAE-06-2014-0025

Mishra, P., Henriksen, D., Kereluik, K., Terry, L., Fahnoe, C., \& Terry, C. (2012). Rethinking technology \& creativity in the 21st Century: Crayons are the future. TechTrends, 56(5), 13-16.

Mishra, P., \& Koehler, M. J. (2006). Technological pedagogical content knowledge: A framework for teacher knowledge. Teachers College Record, 6 (108), 1017-1054.

Noble, H., \& Smith, J. (2015). Issues of validity and reliability in qualitative research. Evidence-Based Nursing, 18(2), 34-35. doi: 10.1136/eb-2015-102054

O’Brien, B. C., Harris, I. B., Beckman, T. J., Reed, D. A., \& Cook, D. A. ( 2014). Standards for reporting qualitative research: A synthesis of recommendations. Academic Medicine, 89(9), 1245-1251.

Ottenbreit-Leftwich, A. T., Glazewski, K. D., Newby, T. J., \& Ertmer, P. A. (2010). Teacher value beliefs associated with using technology: Addressing professional and student needs. Computers \& Education, 55(3), 1321-1335. doi: 10.1016/j.compedu.2010.06.002

Praag, B. V., \& Sanchez, H. S. (2015). Mobile technology in second language classrooms: Insights into its uses, pedagogical implications, and teacher beliefs. ReCALL, 27(3), 288-303. doi: doi:10.1017/S0958344015000075

Richards, J. C. (2010). Competence and performance in language teaching. RELC Journal, 41(2), 101-122.

Robson, C. (2011). Real world research (3rd ed.). Chichester: Wiley.

Şen, Ş., \& Temel, S. (2016). An analysis of prospective Chemistry teachers' attitudes towards information and communication technologies, and of their confidence in technological and pedagogical content knowledge. Participatory Educational Research (Special Issue 2016-II ), 1-10.

Shohel, M. M., \& Power, T. (2010). Introducing mobile technology for enhancing teaching and learning in Bangladesh: Teacher perspectives. Open Learning: The Journal of Open and Distance Learning, 25(3), 201-215. doi: $10.1080 / 02680513.2010 .511953$

Stake, R. E. (1995). The art of case study research. Thousand Oaks, CA: Sage.

Stake, R. E. (2006). Multiple case study analysis. New York, NY: Guilford.

Tellis, W. M. (1997). Introduction to case study. The Qualitative Report, 3(2), 1-14.

Tour, E. (2012). TESOL in times of change. Monash University Linguistics Papers, $8(1), 11-19$. 
Tour, E. (2015). Digital mindsets: Teachers' technology use in personal life and teaching. Language Learning \& Technology, 19(3), 124-139.

Uluyol, Ç., \& Sahin, S. (2016). Elementary school teachers' ICT use in the classroom and their motivators for using ICT. British Journal of Educational Technology, 47 (1), 65-75. doi: doi:10.1111/bjet.12220

Yazan, B. (2015). Three approaches to case study methods in education: Yin, Merriam, and Stake. The Qualitative Report, 20(2), 134-152.

Yin, R. K. (2009). Case study research: Design and methods (4th ed.). Los Angeles, CA: Sage.

Yuksel, I., \& Yasin, E. (2014). Cross-sectional evaluation of English language teachers' technological pedagogical content knowledge. Educational Research Quarterly, 38(2), 23-42.

Zein, S. (2016). Professional development needs of primary EFL teachers: Perspectives of teachers and teacher educators. Professional Development in Education, 1-21. doi: $10.1080 / 19415257.2016 .1156013$ 